\title{
Beauplan's Ukraine: open access georeferenced databases for studies of early modern history of Central and Eastern Europe
}

Abstract

In 1630, Guillaume Le Vasseur, sieur de Beauplan, travelled to the lands of Poland-Lithuania to begin a seventeen-year military career in the Crown army. The purpose of the Beauplan's Ukraine (BU) project is to provide a set of open access, georeferenced databases for the populated places, rivers, river fords, river rapids, islands, forests, mountains, valleys, and travel paths that are shown on a selection of maps created by Beauplan. The purpose of this document is to describe how these databases and related materials can be accessed and applied by scholars, with the ultimate goal of this work being to convert the rich source of information provided by Beauplan's maps into a viable instrument for the laboratory of the historian of south-eastern Europe in Early Modern times.

Keywords

Beauplan • Ukraine $\cdot$ Poland $\bullet$ Lithuania $\cdot$ Ottoman Empire $\bullet$ frontier studies

(C) University of Warsaw - Faculty of Geography and Regional Studies
Michael Polczynski', Mark Polczynski ${ }^{2}$

${ }^{1}$ History Department, Georgetown University, USA e-mail: michaelpolczynski@georgetown.edu

${ }^{2}$ College of Engineering, Marquette University, USA e-mail: mark.polczynski@marquette.edu
Introduction

Guillaume Le Vasseur, sieur de Beauplan (c. 1600-1673) was a French-Polish cartographer, engineer, and architect who served as an artillery captain in the army of the Crown of the Kingdom of Poland between 1630 and 1648 under Sigismund III and Władysław IV. In 1639 Beauplan created the first descriptive map of Ukraine. ${ }^{1}$ His La description d'Ukraine was first published in 1651, and by 1654 he was in Danzig (Gdańsk) working with the well-known cartographer, Willem Hondius. His accounts of this period provide a tableau of seventeenth century Ukrainian landscapes, peoples, flora, and climate, as well as major cartographic descriptions of the region.

The purpose of the Beauplan's Ukraine (BU) project is to provide a set of open access, georeferenced databases for the populated places, rivers, river fords, river rapids, islands, forests, mountains, valleys, and travel paths shown on a selection of Beauplan's maps. This document describes how these databases and related materials can be accessed and applied by scholars, with the ultimate goal of this work being to convert the very rich source of information provided by Beauplan's maps into a viable instrument for the laboratory of the historian of south-east Europe in Early Modern times.

This document starts with a breakdown of the elements of the $\mathrm{BU}$ project followed by a review of the primary and modern

\footnotetext{
${ }^{1}$ Some explanation of the name Ukraine is in order. In the time of Beauplan's service, Ukraine, as a political entity, did not exist. During this time the meaning of the name was frontier ( $u$ kraine), specifically the frontier between the palatinates of Braclaw and Kiew, the Ottoman Empire, and the Tatar Khanate of Crimea. This region was also known at the time as the "wild fields," or "kipchak wastes" in English, deşt-i kıpçak to the Ottomans, and Loca Deserta and Dzike Polia on several of Beauplan's maps.
}

sources used to create the project materials. The fields of the primary $\mathrm{BU}$ database are then described; and the means of accessing the databases and supporting documentation are provided, with special emphasis on quantifying name and location confidence. An actual example of how the project's materials have been applied is presented in order to shed light on a particular research question. The potential for future work is then outlined, and concluding comments describe how this work relates to other georeferenced databases for historical places.

\section{Beauplan's Ukraine Project Overview}

The BU project currently includes four related elements. The primary and modern data sources used to create the databases that are associated with these elements are described in following sections:

- $\quad$ Base Maps of Ukraine (BMU) - provides rivers and terrain elevation base maps that can be used by GIS applications such as Google Earth, ArcGIS, and QGIS. These base maps are used to assist in the creation of the other three elements of the BU project, and can also be used by researchers to support their GIS-based work in this region of the world. The rivers base map is a ".shp" line format file that traces over 650 rivers; while the terrain elevation base map is a set of 180 ".tif" raster format files covering latitudes $\mathrm{N} 46^{\circ}$ to $\mathrm{N} 55^{\circ}$ and longitudes $\mathrm{E} 22^{\circ}$ to $\mathrm{E} 39^{\circ}$.

- Gazetteer of Beauplan's Ukraine (GBU) - provides georeferenced databases in ".shp" and ".csv" point format files for over 3,000 of the populated places, rivers, river 
MISCELLANEA GEOGRAPHICA - REGIONAL STUDIES ON DEVELOPMENT

Vol. 23 • No. 3 • 2019 • pp. 185-193 • ISSN: 2084-6118 • DOI: 10.2478/mgrsd-2019-0015

Table 1. The Beauplan maps used to construct BU materials.

\begin{tabular}{|c|c|}
\hline Status & Beauplan Map Name \\
\hline- & Basse Podolie ou Palatinat de Braclaw \\
\hline- & Basse Volhynie ou palatinat de Kiow \\
\hline- & Borysthensis Fluvii Pars Ultraliminaris vulgo Zaporoże \\
\hline- & Borysthensis Fluvij Pars á Fortalitio Kudak \\
\hline- & Carte d'Ukranie Contenant plusieurs Provinces comprises entre les Confins de Moscovie \\
\hline Done & Delineatio generalis Camporum Desertorum vulgo Ukraina \\
\hline- & Delineatio Provinciæ Tartarorum nunc Crim Antiquitus verò Tauricia Chersonesus dictæ \\
\hline- & Delineatio Provinciæ Turcicæ Budziak dictæ \\
\hline Done & Delineatio specialis et accurata Ukrainae - Czerkasy Kaniow - Panel 2 \\
\hline Done & Delineatio specialis et accurata Ukrainae - Dzikie Pole - Panel 1 \\
\hline Done & Delineatio specialis et accurata Ukrainae - Halicz - Panel 4 \\
\hline Done & Delineatio specialis et accurata Ukrainae - Kamieniec Podolski - Panel 3 \\
\hline Done & Delineatio specialis et accurata Ukrainae - Kijow - Panel 6 \\
\hline Done & Delineatio specialis et accurata Ukrainae - Putywl Baturyn Łochwica - Panel 5 \\
\hline Done & Delineatio specialis et accurata Ukrainae - Zytomierz Berdyczow - Panel 7 \\
\hline Done & Delineatio specialis et accurata Ukrainae -Lwow Luck Tarnopol - Panel 8 \\
\hline- & Haute Podolie ou Palatinat de Kamieniec \\
\hline- & Haute Volhynie ou Palatinat de Lusuc \\
\hline- & La Pologne \\
\hline- & Le Royaume de Pologne Comprenant les Etats de Pologne et de Lithuanae \\
\hline- & Nova totius Regni Poloniae Magniq. ducatus Lithuanae \\
\hline- & Regni Poloniae magnique ducat Lithuaniae nova \\
\hline- & Russie Noire divisee en ses Palatinats \\
\hline- & Tractus Borysthensis Vulgo Dniepr et Niepr dicti, à Bouzin usque ad Chortyca Ostrow \\
\hline- & Tractus Borysthensis Vulgo Dniepr et Niepr dicti, à Chortika Ostro ad Urbem Oczakow \\
\hline- & Tractus Borysthensis Vulgo Dniepr et Niepr dicti, à Kiovia ad Urbum Oczakow \\
\hline- & Tractus Borysthensis VulgoDniepr at Niepr dicti, à Kiovia usuqe ad Bouzin \\
\hline- & Typus Generalis Ukrainae sive Palatinatuum Podoliae Kioviensis et Braczlaviensis \\
\hline- & Ukrainae pars quae Barclavie palatinatus vulgo dicitur \\
\hline- & Ukrainae pars quae Kiovia palatinatus vulgo dicitur \\
\hline
\end{tabular}

Source: Author's work

rapids, river fords, islands, forests, mountains, and valleys shown on Beauplan maps. These databases comprise the primary output of the BU project. The contents and structure of these GBU databases will be described in detail in a following section.

- $\quad$ 17th Century Szlak Paths (BSZLAK) - traces the Czarny, Kuczmanski, and Moraski travel paths as shown on Beauplan's maps. BSZLAK paths are provided as ".shp" line format files.

- $\quad$ Sawrań/Kodyma Border Dispute (SKBD) - provides insights into the 1542 border dispute between Poland-Lithuania and the Ottoman Empire. SKBD uses the other three BU elements to trace the conflicting border claims, with the claimed border lines being provided as a ".shp" line format file. This element of the BU is described in greater detail in a following section.

\section{Primary BU Data Sources}

As stated, the purpose of the BU project is to create and make available georeferenced databases of the places shown on Beauplan's maps. ${ }^{2}$ Currently, places on nine of the maps listed in Table 1 have been georeferenced. In addition to the maps themselves, the modern publication of Beauplan's original La description d'Ukraine (Pernal \& Esser 1990) constitutes a critical primary source for the BU project.

To get an idea of what these primary sources look like, Figure 1 shows Beauplan's Delineatio generalis Camporum Desertorum vulgo Ukraina map, and Figure 2 shows a detailed

${ }^{2}$ Regarding the representation of the region named Ukraine on Beauplan's maps (see previous footnote): the maps cover the greater part (southeast) of the Rzeczpospolita Polska in the time of Sigismund III and Władysław IV Vasa, as well as the territory of the Romanian Principality of Moldavia. Budziak, on Beauplan's maps, is a part of this last-mentioned principality. In total, the maps represent Beauplan's knowledge of the region between the Oriental-Carpathian mountains and Dnieper river 




Figure 1: Beauplan's Delineatio generalis Camporum Desertorum vulgo Ukraina map. See Figure 2 for detail. Available from: Beauplan, Guillaume Le Vasseur, Sieur De, Approximately, and Willem Hondius. Delineatio generalis Camporum Desertorum vulgo Ukraina: cum adjacentibus provinciis. [Gedanum: Beauplan, 1648] Map. Retrieved from the Library of Congress, <www.loc.gov/ item/80692351/>. [8 May 2019] 


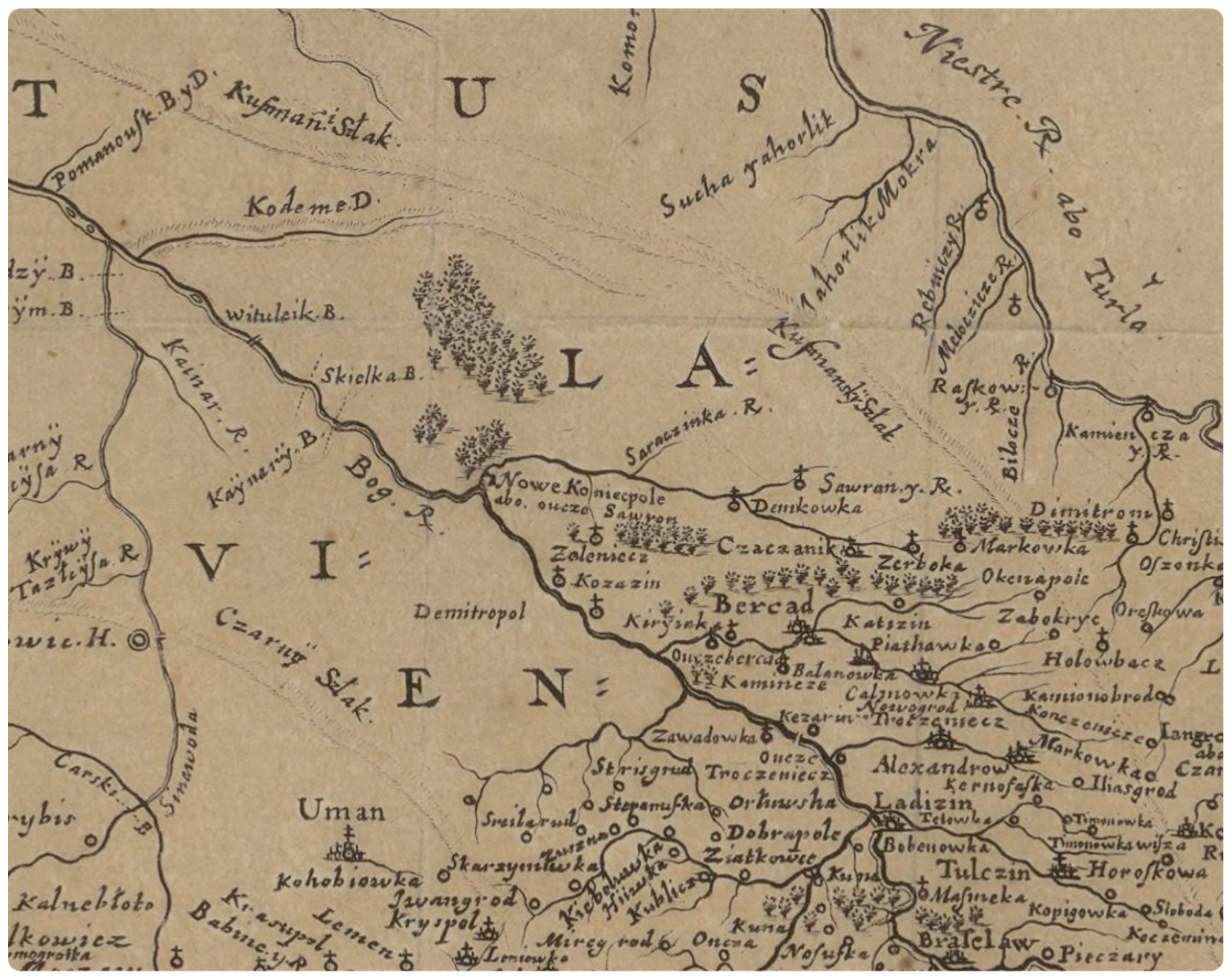

Figure 2: Detail from the map in Figure 1. Available from: Beauplan, Guillaume Le Vasseur, Sieur De, Approximately, and Willem Hondius. Delineatio generalis Camporum Desertorum vulgo Ukraina: cum adjacentibus provinciis. [Gedanum: Beauplan, 1648] Map. Retrieved from the Library of Congress, <www.loc.gov/item/80692351/>. [8 May 2019]

view of the map from Figure 1. Concerning these figures, it is interesting to note that many of Beauplan's maps have north at the bottom. This makes sense from the perspective of a PolishLithuanian military commander who is examining a map while looking south toward Ottoman lands, since north-to-south would be the direction of a march in times of conflict.

\section{Modern Data Sources}

The places on Beauplan's maps are located through their association with currently-existing landmarks. Latitudes and longitudes for the majority of Beauplan's places were obtained by associating these places with places in the GeoNames geographical database (GeoNames 2018). For those of Beauplan's places that could not be associated with GeoNames places, Google's physical map (Google Maps 2018) was checked. River courses for the BMU base map were traced from Google's physical map, and the BMU terrain elevation base map set was derived from Shuttle Radar Topography Mission data (USGS 2018).

\section{GBU Database Fields}

With entries for over 3,000 different places (over 4,000 total entries to date, since some places are shown on multiple maps) the database of populated places, rivers, river rapids, river fords, islands, forests, mountains, and valleys generated by the GBU element of the BU project is the largest and most complex of the $\mathrm{BU}$ project databases. This section provides an overview of the GBU database fields. Detailed descriptions of the name and location confidence fields are given in the following section.

The thirteen GBU database fields are shown in Table 2. The first column in the table gives the field name, the second column provides a brief description of the field, and the third provides an actual example taken from the GBU database.

Concerning the gazbu-entry field in Table 2, every entry in the database has a unique ID, which is given as a URL for a BU project web page associated with the entry. The gazbu-id field in Table 2 gives a unique ID which is assigned to each particular place in the database. It is critical to note the difference between the gazbu-entry and gazbu-id fields. A particular place may appear on multiple maps with multiple spellings on each map. Such a place will have a different entry for each map/spelling occurrence, but all such entries will have the same gazbu-id since all entries are associated with the same place.

An entry's gazbu-map value provides access to an on-line digitized version of the particular map on which the entry can be found. For example, following the URL link in the gazbu-map field of Table 2 leads to a BU project website which in turn provides a URL link to an on-line digital version of the Delineatio specialis et accurata Ukrainae - Czerkasy Kaniow - Panel 2 map, which is the map on which the associated entry is located.

The gazbu-grid field helps users find a particular place on a map. Beauplan's maps typically include latitude and longitude markers along the edges of the map; and a map grid is created 
Table 2: GBU database fields.

\begin{tabular}{|c|c|c|}
\hline Database Field & Description & Example \\
\hline gazbu-entry & Unique ID assigned to each database entry & http://gazbu.org/entry/12.htm \\
\hline gazbu-id & Unique ID assigned to each place in the database & gazbu-10 \\
\hline gazbu-map & Map on which the database entry can be found & http://gazbu.org/map/ds2.htm \\
\hline gazbu-grid & Map grid where this entry can be found & R12 \\
\hline gazbu-class & Type of place as shown on the map & Krywy Taszłeys \\
\hline gazbu-name & Name as spelled on the map & Krywy Taszleys \\
\hline gazbu-name-confidence & Confidence of name spelling & http://gazbu.org/name-confidence/2.htm \\
\hline latin-name & Name with Latin characters & 30,89544 \\
\hline gazbu-latitude & Place latitude & http://gazbu.org/location-confidence/1.htm \\
\hline gazbu-longitude & Place longitude & http://www.geonames.org/830038/ \\
\hline gazbu-location-confidence & Confidence of latitude and longitude & https://orcid.org/0000-0001-5427-7601 \\
\hline geonames-id & GeoNames ID of associated place & \\
\hline contributor-id & ID of person contributing entry & \\
\hline
\end{tabular}

Source: Author's work

Table 3: Latitude and longitude grid square labeling scheme.

\begin{tabular}{|c|c|c|c|c|c|c|c|c|c|c|c|c|c|c|c|c|c|c|c|c|c|c|c|c|c|c|}
\hline Longitude & A & B & C & D & E & F & G & H & I & J & K & L & M & N & O & P & Q & R & S & T & U & V & W & X & Y & Z \\
\hline From & 37 & 38 & 39 & 40 & 41 & 42 & 43 & 44 & 45 & 46 & 47 & 48 & 49 & 50 & 51 & 52 & 53 & 54 & 55 & 56 & 57 & 58 & 59 & 60 & 61 & 62 \\
\hline To & 38 & 39 & 40 & 41 & 42 & 43 & 44 & 45 & 46 & 47 & 48 & 49 & 50 & 51 & 52 & 53 & 54 & 55 & 56 & 57 & 58 & 59 & 60 & 61 & 62 & 63 \\
\hline
\end{tabular}

\begin{tabular}{|c|c|c|c|c|c|c|c|c|c|c|c|c|c|c|c|}
\hline Latitude & $\mathbf{1}$ & $\mathbf{2}$ & $\mathbf{3}$ & $\mathbf{4}$ & $\mathbf{5}$ & $\mathbf{6}$ & $\mathbf{7}$ & $\mathbf{8}$ & $\mathbf{9}$ & $\mathbf{1 0}$ & $\mathbf{1 1}$ & $\mathbf{1 2}$ & $\mathbf{1 3}$ & $\mathbf{1 4}$ & $\mathbf{1 5}$ \\
\hline From & 59 & 58 & 57 & 56 & 55 & 54 & 53 & 52 & 51 & 50 & 49 & 48 & 47 & 46 & 45 \\
\hline To & 60 & 59 & 58 & 57 & 56 & 55 & 54 & 53 & 52 & 51 & 50 & 49 & 48 & 47 & 46 \\
\hline
\end{tabular}

Source: Author's work

for a particular map by drawing grid lines between these markers. Table 3 shows the grid square labeling scheme used for all maps included in the GBU database. For example, database entry 12 in Table 2 appears in grid square R12, which lies between $54^{\circ}$ and $55^{\circ}$ longitude and $48^{\circ}$ and $49^{\circ}$ latitude on the Delineatio specialis et accurata Ukrainae - Czerkasy Kaniow - Panel 2 map.

Places on Beauplan's maps are classified according to eight gazbu-class values in the GBU database: frd=river ford, $f s t=$ forest, isl=island, $m n t=$ mountain, $p o p=$ populated place, rap=river rapids, riv=river, and val=valley. The database's gazbuclass values are URLs that link to BU project web pages that provide a description of each of the classes.

The gazbu-name field contains an entry's name as spelled on the Beauplan map from which the name was taken. Since names are not always legible - especially with regard to special characters such as $\ddot{y}$ - a gazbu-name-confidence level of 1 through 5 is assigned to the database entries: where level 1 indicates that all letters in the name are clearly legible, and level 5 indicates that the name is illegible. The field values are $\mathrm{BU}$ project URLs linked to descriptions of the levels, with the confidence level appearing as a numeric value in the URL: for the example given in Table 2 , the name confidence level $=2$.

Comparing the gazbu-name and the latin-name example values in Table 2 illustrates how special characters change in the Latin versions of names. For example, the $\ddot{y}$ character in a
Beauplan map spelling is replaced with a $y$ character in the GBU database's Latin version of the name. The database contains the Latin spellings of Beauplan map names in order to facilitate database searches.

The locations of all the places included in the GBU database are given as a single latitude/longitude point pair, located at the approximate center of the place. The exceptions are river locations where the latitude and longitude are given for the mouth of the river, and forest locations where the approximate center of the forest is given. As mentioned previously, GBU database entry locations are taken primarily from the associated GeoNames database places, with locations being entered into the gazbulatitude and gazbu-longitude fields.

The GeoNames database includes a URL for each database entry, with the URL linking to a web map centered on the place indicated in the database. This GeoNames URL appears in the GBU geonames-id field. For cases where a Beauplan place does not appear in the GeoNames database, but does appear on the Google Physical map, the place has been added to the GeoNames database at the location shown on the Google Physical map, thereby providing a geonames-id value and a location for the place. If a Beauplan place cannot be located on any modern source, then this field contains the following value: http://www.gazbu.org/geonames-id-none/. 
The gazbu-location-confidence field reflects the strength of the association between the Beauplan map place and the associated GeoNames place. A location confidence level of 1 through 5 is assigned to each entry: with level 1 indicating a strong association between a historical place name and a modern place name, and level 5 indicating no association between a historical place name and a modern place name as well as a weak association with surrounding landmarks. As with gazbu-name-confidence, field values are linked to descriptions of the levels, with the confidence level appearing as the numeric value in the URL.

The contributor-id field contains a URL for the contributor of an entry. Ideally, this field contains a stable and robust means for contacting the contributor. The authors suggest using an ORCiD identifier for the contributor-id, since this offers a persistent URL as opposed to an identifier such as an e-mail address that can change over time.

One critical aspect of the design of the GBU database needs to be emphasized. When executing a multi-year project requiring several iterations through the database's generational process, changes and constant additions are to be expected. This situation is exacerbated if different sources are used to create the database and/or if several people are contributing to the database. One way of minimizing the resulting coordination problems is to exclude data that is reliably and robustly stored in some other reputable database. In accordance with this rationale, the GBU database does not include fields for modern primary, alternate modern, or historical place names. Instead the database includes the geonames-id field containing links to the GeoNames database, which already contains modern primary and alternative names for places in multiple languages and scripts, and also allows specific names to be designated as historical names along with the time period in which the historical name applied to the place. As a point of reference, GeoNames provides at least 80 alternative names for the populated place, Kyiv (Beauplan map Kiiow and Kÿowia), and over 89 alternative names for Lviv (Beauplan map names Lemburg, Leopolis, and Lwow). In essence, the GBU relies on proactive GeoNames users to manage the modern primary names and alternate names for places.

\section{Name and Location Confidence}

Some comments on the GBU database's name and location confidence levels are in order. The rules used to assign name confidence are as follows:

1. All letters in name are clearly legible.

2. Not certain if/which special characters are used in the name.

3. One or two letters in the name are not clearly legible.

4. Name is partially legible.

5. Name is illegible.

The rules for location confidence are:

1. Strong association between the historical place name and modern place name.

2. Strong association between the historical place name and modern place name, but several modern places in the area have some form of name qualifier, for example, stary vs. nowe.

3. Weak association between the historical place name and modern place name.

4. No association between the historical place name and modern place name, but strong association with a modern place with a different name based on surrounding landmarks.

5. No association between the historical place name and modern place name, and weak association with surrounding landmarks.

These rules are more subjective than objective, but the authors have been unable to settle on any existing concise, consistent, and generally-applicable scheme for quantifying the confidence of names and locations taken from historical sources such as Beauplan's maps. It appears that this is an area for continued improvement in the field of historical GIS, and the authors are eager to learn of any schemes that could be applied to their work.

\section{Access and Licensing of BU Project Materials}

The BU project team encourages scholars of the early modern history of Central and Eastern Europe to utilize BU project materials for their studies. All materials are available for download through the project's repository (Beauplan's Ukraine 2018), including extensive documentation on the $\mathrm{BU}$ elements beyond the brief descriptions provided here. Periodic BU project updates are communicated via the project's log (ResearchGate Beauplan's Ukraine 2018).

The contents of the GBU, BSZLAK, and SKBD can be viewed as Harvard Worldmap web maps (World Map - BSZLAK 2018; World Map - GBU 2018; World Map - SKBD 2018) and QGIS Cloud web maps (QGIS Cloud - BSZLAK 2018; QGIS Cloud - GBU 2018; QGIS Cloud - SKBD 2018). The Gazetteer of Beauplan's Ukraine database can be searched on-line using the Google search engine and the search term site: gazbu.org/entry/ [name of Beauplan place]. Note that adding the site: gazbu.org/entry/ portion to the Google search term limits the search to GBU database entries.

All BU materials are offered through Creative Commons Public Domain Dedication. The authors dedicate this work to the public domain by waiving all rights to the work worldwide. Users may copy, modify, and distribute the work without asking permission, although the project team would appreciate the citation of this publication when using BU materials.

\section{Application of BU Project Materials}

In general, databases have no intrinsic value - the benefit is derived from the application of a database in order to answer questions and solve problems. The SKBD element of the $\mathrm{BU}$ project demonstrates how the other three elements of the $\mathrm{BU}$ project can be used to provide a geographical context for understanding the cause of the 1539-1542 border dispute between Poland-Lithuania and the Ottoman Empire (Polczynski 2017).

In 1539 a proposal for a joint border demarcation commission to establish the border between the Ottoman Empire and PolandLithuania was sent by the Ottoman sultan, Süleymân to the Polish king, Zygmunt I. By 1542, the issue had boiled down to a dispute over whether the border should extend between the Dniester river and the Pivdennyy Buh river along the Sawrań river (Ottoman proposal), or along the Kodyma river (Polish proposal) While detailed period accounts of the negotiations exist, the goal of SKBD was to expand the understanding of the situation by addressing a number of questions. Where are the Dniester, Pivdennyy Buh, Sawrań, and Kodyma rivers? Were there any settlements, travel paths, river fords, forests, or other resources of importance within the disputed area? Ultimately, was this a struggle for control of a strategic resource-rich territory, or fundamentally a war of wills over a small, worthless plot of land? Although Beauplan's travels through this area were conducted almost one hundred years after the border dispute, his maps can shed light on these questions.

Figures 3 and 4 were constructed using BMU, GBU, and BSZLAK materials (See Figure 2 for an equivalent section of Beauplan's Delineatio generalis Camporum Desertorum vulgo Ukraina map). As shown in Figure 3, prior to the dispute, Poland-Lithuania claims ran as far south as the Black Sea and up along the Dnieper river. Figure 4 shows the Sawrań/Kodyma region in greater detail. The figures show that retreating to either 


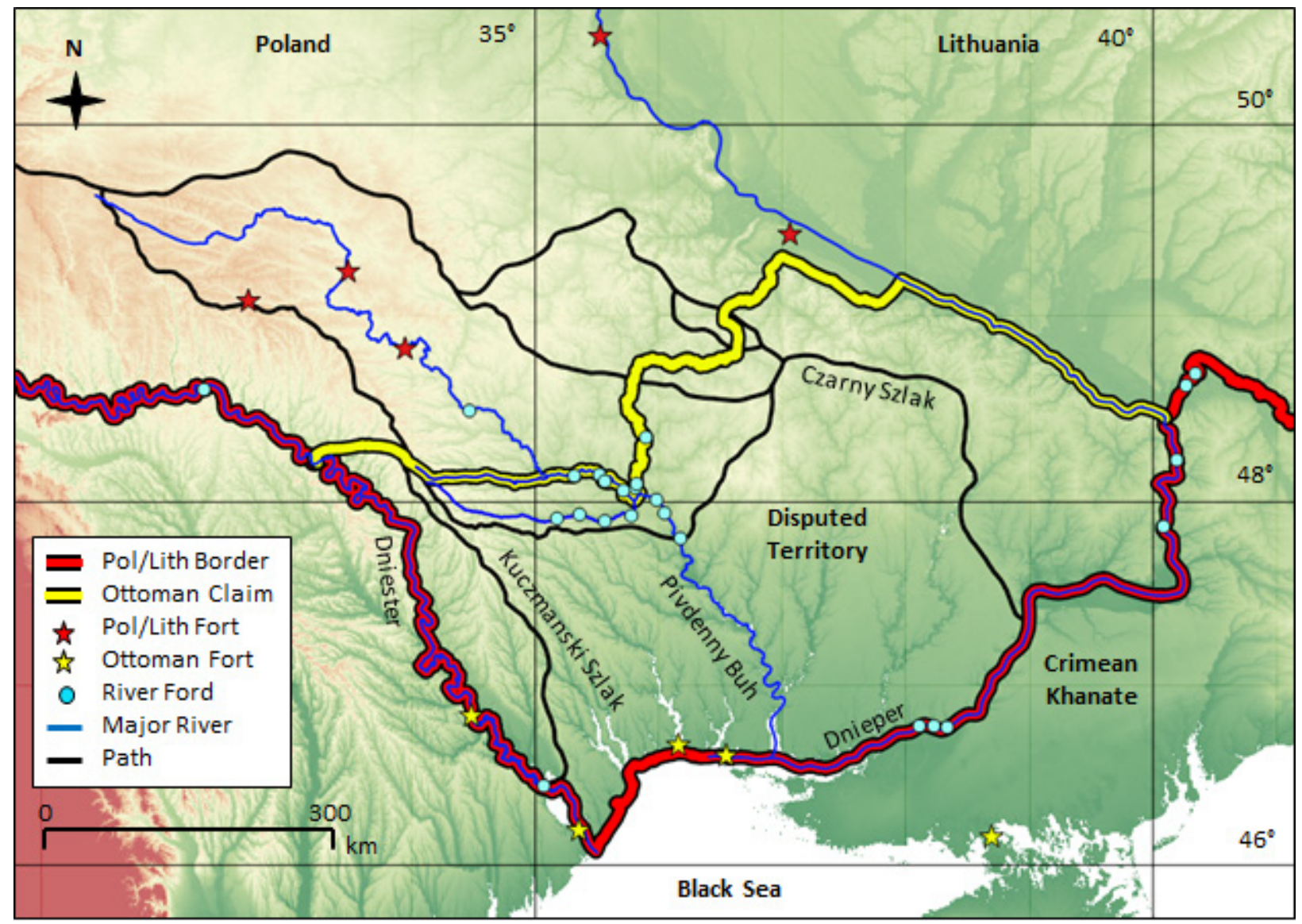

Figure 3: The general region of 1539-1542 border dispute between Poland-Lithuania and the Ottoman Empire. Source: Author's work

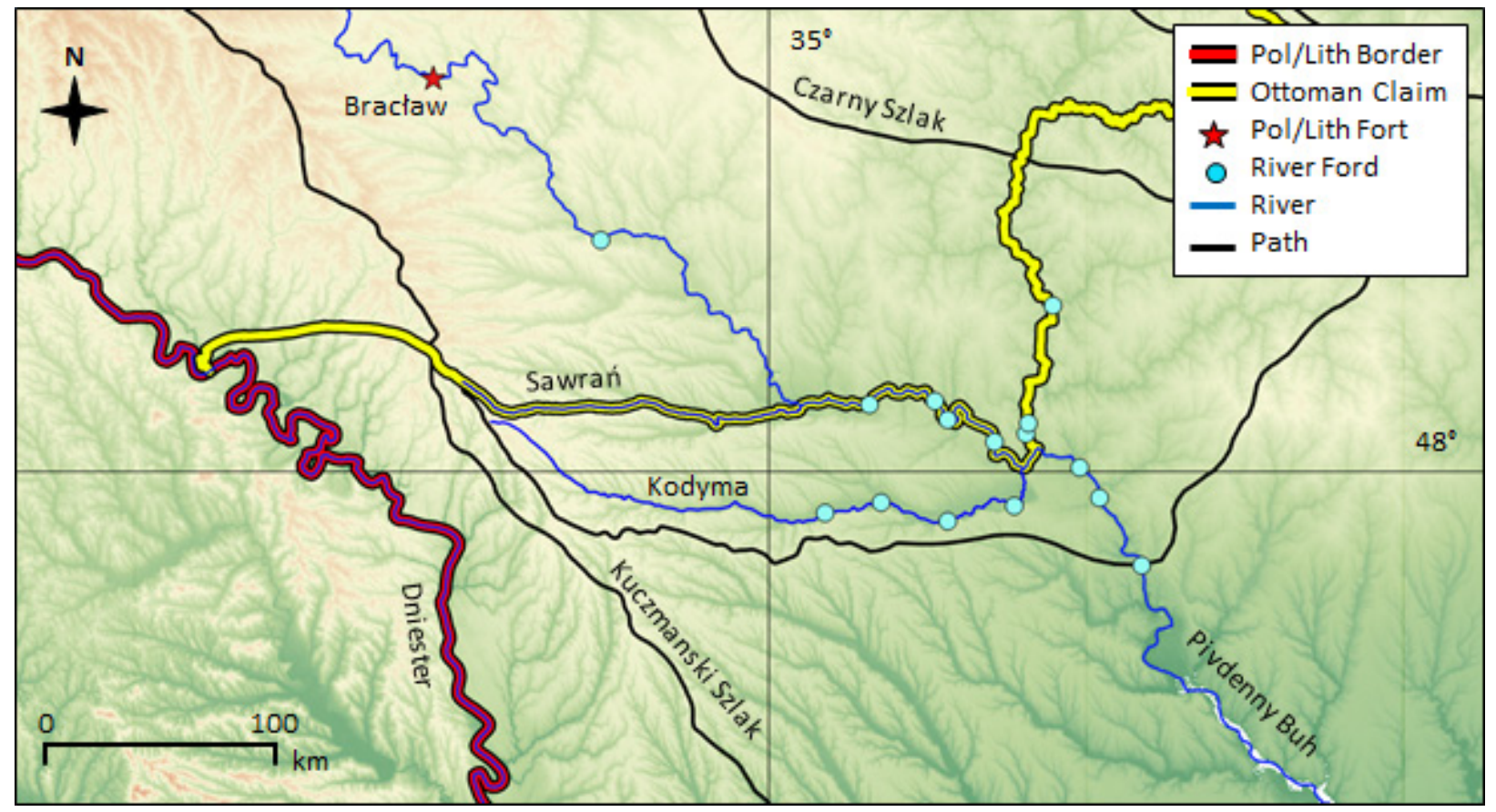

Figure 4: Sawrań/Kodyma river border dispute between Poland-Lithuania and the Ottoman Empire. Source: Author's work 


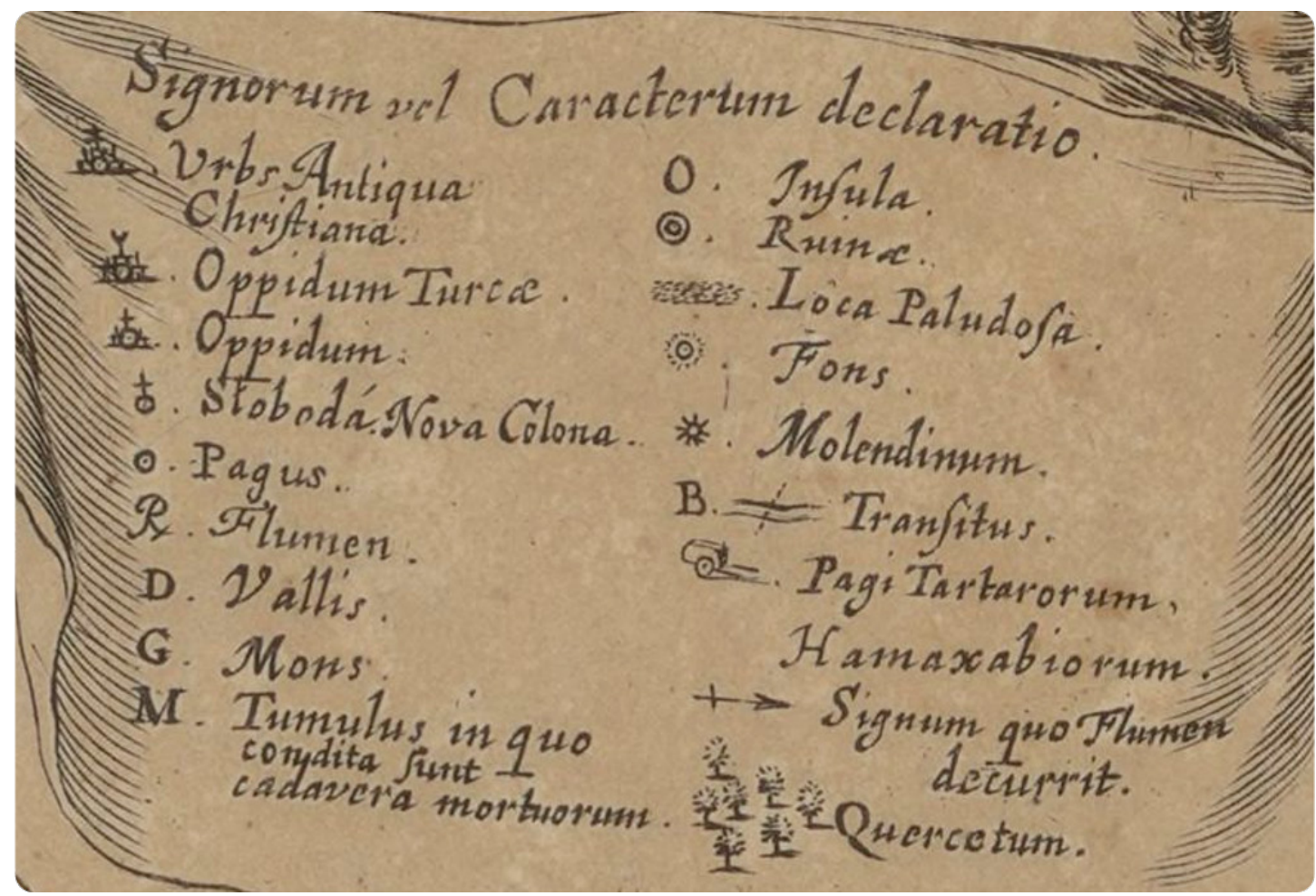

Figure 5: Place types as designated on the map in Figure 1. Available from: Beauplan, Guillaume Le Vasseur, Sieur De, Approximately, and Willem Hondius. Delineatio generalis Camporum Desertorum vulgo Ukraina: cum adjacentibus provinciis. [Gedanum: Beauplan, 1648] Map. Retrieved from the Library of Congress, <www.loc.gov/item/80692351/>. [8 May 2019]

the Sawran or Kodyma river would have constituted a major concession by Zygmunt I. That being said, the area between these rivers is small relative to the size of the conceded territory, so why was control of this area under dispute?

Beauplan's maps show a high concentration of river fords in this area, with the Czarny path and Kuczmanski path running in the vicinity of the disputed territory. Figures 3 and 4 clearly shows that the Sawrań/Kodyma territory constituted a strategic attack and defense corridor/bottleneck between Polish-Lithuanian lands to the northwest, and the Ottoman lands to the southeast. Control of the territory up to the Kodyma river would give Zygmunt I a strategic military advantage, while control up to the Sawrań river would give that advantage to Süleymân. As a post script, negotiations ultimately broke down, with no hard border existing in this region for the next hundred years.

\section{Future Work}

The purpose of the BU project is to provide a set of open access, georeferenced databases of populated places, rivers, river fords, river rapids, islands, forests, mountains, valleys, and travel paths as shown on Beauplan's maps, but there is a wealth of information in the maps beyond what is currently being extracted for the BU databases. Figures 1, 2, and 5 provide a sample illustration of the full range of information available from the maps. This type of information is exceedingly valuable for work such as the study of the seventeenth century frontier between Poland-Lithuania and the Ottoman Empire. See, for example, (Polczynski \& Polczynski 2014), where the classification of populated place types per the example of Figure 5 could greatly benefit the quantitative assessment of defensive networks along the frontier. Other interesting types of information provided by Beauplan's maps include a seventeenth century view of regional boundaries. The extraction of such information provides fertile ground for potential future work.

Another opportunity for future work lies in the addition of Beauplan map place names to the GeoNames database. As noted, the GBU database links Beauplan map places to GeoNames entries wherever associations can be made. Given GeoNames' simple process for adding alternative historical names to places, these Beauplan names could be added to GeoNames, thereby providing another way to search for Beauplan places in addition to using Google's search engine to search the GBU database as described above.

\section{Concluding Remarks}

It has taken over three years to generate a gazetteer of the $4,000+$ entries for places appearing on nine Beauplan maps, with an additional two years of work anticipated for the remaining maps in Table 1. That being said, our work is extremely modest compared to efforts such as Pleiades (Pleiades 2019), Pelagios (Pelagios 2019), the World-Historical Gazetteer (World Historical Gazetteer 2019), and the Cultures of Knowledge project (Cultures of Knowledge 2019), but it is important to recognize the fundamentally different scope of the BU's work compared to these resources. While projects such as those just cited provide comprehensive databases for, in some cases, vast geographical areas over centuries of time, using sophisticated approaches such as linked open data, the BU project attempts only to make a very limited set of primary sources (Beauplan's maps) - covering a short period of time (about 20 years) and a relatively small area (modern Ukraine vs. the entire ancient Greek and Roman worlds and beyond in the Pleiades example) - available to scholars focused on addressing issues such as the 1539-1542 border dispute between Poland-Lithuania and the Ottoman Empire (the original 
impetus for this work). This narrowly-scoped project focuses on transforming a limited, but rich source of information (Beauplan's maps) into a viable instrument for the laboratory of the historian of south-east Europe in Early Modern times and especially in the seventeenth century.

Given this limitation, the BU team fully appreciates the potential benefits of integrating BU's work with more comprehensive projects of greater scope. To this end, the team has opened discussions with Pleiades and Pelagios, with future team efforts directed toward exploring a means of providing better and wider access to $\mathrm{BU}$ project materials. For updates on these efforts, check the BU project log and the project's repository.

\section{References}

Beauplan's Ukraine, 2018. Available from: <https://dataverse. harvard.edu/dataverse/BU>. [29 January 2019].

Cultures of Knowledge, 2019. Available from: < http://www. culturesofknowledge.org/>. [29 January 2019].

GeoNames, 2018. Available from: <http://www.geonames.org/>. [29 January 2019].

Google Maps, 2018. Available from: <https://www.google.com/ maps/>. [29 January 2019].

Pelagios, 2019. Available from: <http://commons. pelagios.org/>. [29 January 2019].

Pernal, AB \& Essar, DF 1993, La description d'Ukraine, Harvard University Press, Cambridge.

Pleiades, 2018. Available from <https://pleiades.stoa.org/>. [29 January, 2019].

Polczynski, MH \& Polczynski, MJ 2014, 'A Microsoft VBA Application for Generating Heat Maps', Transactions in GIS, vol. 17 , no. 1 , pp. 148-157.

Polczynski, MJ 2017, The Wild Fields: Power and space in the Early Modern Polish-Lithuanian/Ottoman Frontier. PhD thesis, Georgetown University, Georgetown.

QGIS Cloud - BSZLAK, 2018. Available from: <https://qgiscloud. com/polczynski/BSZLAK_Web_Map>. [29 January 2019].

QGIS Cloud - GBU, 2018. Available from: <https://qgiscloud.com/ polczynski/GBU_Web_Map>. [29 January 2019].

QGIS Cloud - SKBD, 2018. Available from: <https://qgiscloud. com/polczynski/SKBD_Web_Map>. [29 January 2019].

ResearchGate, 2018, Beauplan's Ukraine. Available from: < https://www.researchgate.net/project/Beauplans-Ukraine>. [29 January 2019].

USGS, 2018, Shuttle Radar Topography Mission (SRTM) 1 Arc-Second Global. Available from <http://ta.cr.usgs.gov/ SRTM1Arc>. [29 January 2019].

World Historical Gazetteer, 2019. Available from: <http:// whgazetteer.org/>. [29 January 2019]. World Map - BSZLAK, 2018. Available from: <https://worldmap.harvard.edu/maps/ BSZLAK>. [29 January 2019].

World Map - GBU, 2018. Available from: <https://worldmap. harvard.edu/maps/GBU>. [29 January 2019].

World Map - SKBD, 2018. Available from: < https://worldmap. harvard.edu/maps/16872>. [29 January 2019]. 